\title{
A New Generation Wireless Mobile Network -5G
}

\author{
Ramnarayan \\ M.Tech research scholar \\ GEU dehradun
}

\author{
Vashu Kumar \\ M.Tech research scholar \\ GRD dehradun
}

\author{
Vipin Kumar \\ M.Tech research scholar \\ PTU Punjab
}

\begin{abstract}
The world has seen a lot of changes in the realm of communication. Today we no more use landlines. Everyone possesses a mobile phone that functions nine to seven. Our handsets not only keep us connected with the world at large but also serve the purpose of entertainment gadget. From $1 \mathrm{G}$ to $2.5 \mathrm{G}$ and from $3 \mathrm{G}$ to $5 \mathrm{G}$ this world of telecommunications has seen a number of improvements along with improved performance with every passing day. This paper aims at highlighting some of the concepts and technologies which will facilitate the affordable provision of very high data rates with virtually ubiquitous coverage and some of its features and benefits in $5 \mathrm{G}$ wireless networks. $5 \mathrm{G}$ is not a term officially used for any particular specification or in any official document yet made public by telecommunication companies or standardization bodies such as 3GPP, WiMAX Forum or ITU-R. The developed world is already utilizing $4 \mathrm{G}$ and it is beyond imagination that what will be engulfed in $5 \mathrm{G}$ as everything is already embedded such as smallest mobile phones, speed dialing, largest memory, audio and video player, Microsoft office, etc[8]. Pico net and Bluetooth technology has made data sharing a child's play. 5G technology is on its way to change the way by which most of the users access their handsets. Users will go through a level of call volume and data transmission with $5 \mathrm{G}$ pushed over a VOIP enables gadget. With increasing awareness of customers with respect to upcoming technologies, affordable packages and good looks; it is very important that mobile producers must give an altogether decent package for keeping up the customer loyalty.
\end{abstract}

\section{General Terms}

$5 \mathrm{G}$ is new revolution is about to Begin it will change the manner in which cellular plans are offered worldwide using Flat IP Network, BDMA, Nanotechnology, and Cloud Computing.

\section{Keywords}

$1 \mathrm{G}, 2 \mathrm{G}, 3 \mathrm{G}, 4 \mathrm{G}, 5 \mathrm{G}$ (next wave)

\section{INTRODUCTION}

The technology or concept of wireless technology is not recent. In fact, the story of wireless phones is dated way back to the middle of the 20th century. Those are the days mobile phones are bulky and are usually found in cars. Since they are big and huge, they are not considered to be portable handset; although they are mobile they are still not that 'mobile'.

It's going to be the next revolution after $2 \mathrm{G}$ Technologies, $3 \mathrm{G}$ Technology and 4G Technology . 5G technology, the latest trend also known as 5th generation technology is becoming the most admired fuel for the cellular phones. With the advent of $5 \mathrm{G}$, global mobility is about to shrink where you can access you entire office on your very advanced PDA or cellular phones. 5G technology is about to offer immensely strengthen data transfer capabilities and exhaustive voice call volumes and data broadcast. If technology experts are to be believed, 5G has a seamless capability to support software and consultancy and well-arranged Router and switching connectivity. The 5G technology has brought up an exhaustive change in the cellular phone market that enables users to access international mobile phones on local flexibilities. This highly vibrant technology wraps up amazing data capabilities with high end data connectivity. As name implies, this is probably the highest improvement over the $1 \mathrm{G}$ , 2G , 3G , and 4G technologies[1]. 5G Technology has considerably changed the entire foray of telecommunication with reliability, improved capacity and lightening data transfer. Data management and compatibility of voice data over the networks are some of the astounding features of this new entrant in the home. It has considerable advantages and positive aspects than its counterparts.

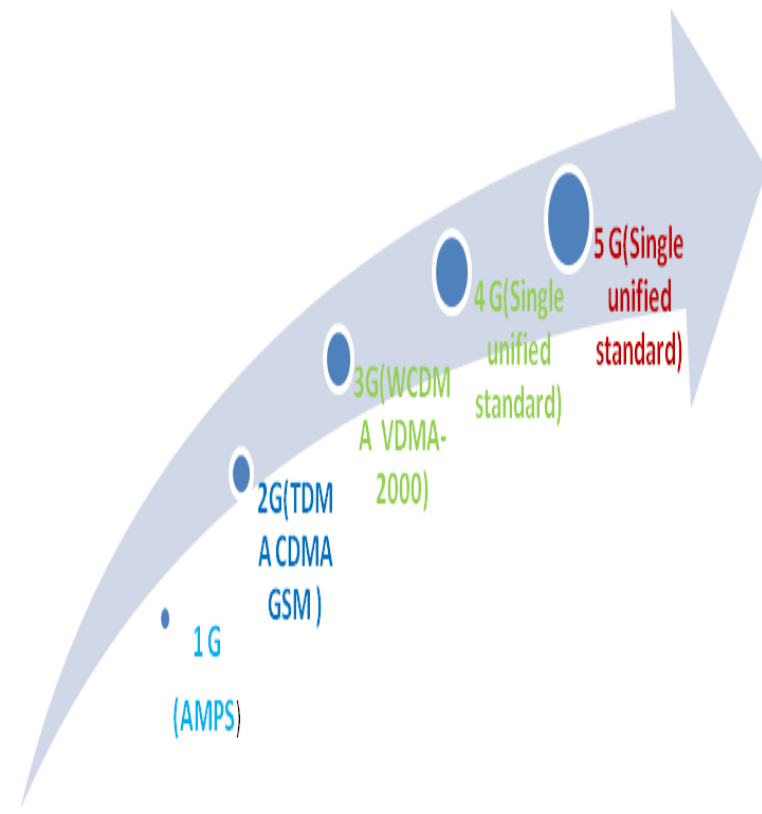

Fig 1: Evolution of next wave

\section{EVOLUTION OF WIRELESS TECHNOLOGY}

The first ever wireless phones were used and probably manufactured in Japan as early as 1979. Today, we keep hearing the $4 \mathrm{G}$ technology in wireless, during those times, it still $1 \mathrm{G}$ generation. Right about the same time, in Northern Europe, NMT, or Nordic Mobile Telephone are also developing the same kind of wireless technology in phones. Just like today where Finland is almost synonymous with a popular cell phone brand, it was NMT in Norway, Sweden, Denmark and Finland where the first wireless phones were used in the Northern are of Europe[9]. A few years later, America made their scene in the wireless phone technology with Motorola mobiles. Their first cellular or mobile phones 
were used in 1983. After America, the rest of the world followed suit - Mexico, United Kingdom, Canada etc.

\section{GENERATION}

\subsection{G: First Generation}

In the 1970s, the First Generation, or 1G, mobile networks were introduced. These systems were referred to as cellular, which was later shortened to "cell", due to the method by which the signals were handed off between towers. Cell phone signals were based on analog system transmissions, and $1 \mathrm{G}$ devices were comparatively less heavy and expensive than prior devices. Some of the most popular standards deployed for $1 \mathrm{G}$ systems were Advanced Mobile Phone System (AMPS), Total Access Communication Systems (TACS) and Nordic Mobile Telephone (NMT). The global mobile phone market grew from 30 to 50 percent annually with the appearance of the $1 \mathrm{G}$ network, and the number of subscribers worldwide reached approximately 20 million by 1990 [4].

\subsection{G: GSM and GPRS Networks}

In the early 1990s, $2 \mathrm{G}$ phones deploying GSM technology were introduced. Global System for Mobile communications or GSM uses digital modulation to improve voice quality but the network offers limited data service. As demand drove uptake of cell phones, $2 \mathrm{G}$ carriers continued to improve transmission quality and coverage. The $2 \mathrm{G}$ carriers also began to offer additional services, such as paging, faxes, text messages and voicemail [5]. The limited data services under $2 \mathrm{G}$ included WAP, HSCSD and MLS. An intermediary phase, $2.5 \mathrm{G}$ was introduced in the late 1990s. It uses the GPRS standard, which delivers packet-switched data capabilities to existing GSM networks. It allows users to send graphics-rich data as packets. The importance for packet-switching increased with the rise of the Internet and the Internet Protocol, or IP. The EDGE network is an example of $2.5 \mathrm{G}$ mobile technology.

\subsection{Recent 3G Networks}

The $3 \mathrm{G}$ revolution allowed mobile telephone customers to use audio, graphics and video applications. Over $3 \mathrm{G}$ it is possible to watch streaming video and engage in video telephony, although such activities are severely constrained by network bottlenecks and over-usage. One of the main objectives behind $3 \mathrm{G}$ was to standardize on a single global network protocol instead of the different standards adopted previously in Europe, the U.S. and other regions. 3G phone speeds deliver up to $2 \mathrm{Mbps}$, but only under the best conditions and in stationary mode. Moving at a high speed can drop 3G bandwidth to a mere 145 Kbps. $3 \mathrm{G}$ cellular services, also known as UMTS, sustain higher data rates and open the way to Internet style applications. 3G technology supports both packet and circuit switched data transmission, and a single set of standards can be used worldwide with compatibility over a variety of mobile devices. UMTS delivers the first possibility of global roaming, with potential access to the Internet from any location.

\subsection{High-Speed 4G Mobile Networks}

The current generation of mobile telephony, 4G has been developed with the aim of providing transmission rates up to $20 \mathrm{Mbps}$ while simultaneously accommodating Quality of Service (QoS) features. QoS will allow you and your telephone carrier to prioritize traffic according to the type of application using your bandwidth and adjust between your different telephone needs at a moment's notice. Only now are we beginning to see the potential of $4 \mathrm{G}$ applications. They are expected to include high-performance streaming of multimedia content. The deployment of $4 \mathrm{G}$ networks will also improve video conferencing functionality. It is also anticipated that $4 \mathrm{G}$ networks will deliver wider bandwidth to vehicles and devices moving at high speeds within the network area[1].

\subsection{G Technology, The next wave}

5G Technology stands for 5th Generation Mobile technology. 5G mobile technology has changed the means to use cell phones within very high bandwidth. User never experienced ever before such a high value technology. Nowadays mobile users have much awareness of the cell phone (mobile) technology [10]. The 5G technologies include all type of advanced features which makes $5 \mathrm{G}$ mobile technology most powerful and in huge demand in near future. The gigantic array of innovative technology being built into new cell phones is stunning. 5G technologies which is on hand held phone offering more power and features than at least 1000 lunar modules. A user can also hook their $5 \mathrm{G}$ technology cell phone with their Laptop to get broadband internet access. 5G technology including camera, MP3 recording, video player, large phone memory, dialing speed, audio player and much more you never imagine. For children rocking fun Bluetooth technology and Pico nets has become in market. Currently $5 \mathrm{G}$ is not a term officially used for any particular specification or in any official document yet made public by telecommunication companies or standardization bodies such as 3GPP, WiMAX Forum or ITU-R[2].

\section{KEY ADVANTAGE OF 5G TECHNOLOGIES [3]:}

As quoted above, 5G technology has offered a number of business advantages to the business organizations and customers in comparison to its previous counterparts. Below are the salient features and advantages that 5th generation technology delivers to the global telecommunication users. These advantages let the service providers deliver some out of the box mobility solutions and affordable cellular plans to the users with full fledged and additional utilities.

1. The technology offers high resolution bi-directional large bandwidth

2. Contains an advanced billing interfaces

3. Providing high end subscriber supervision tools

4. Large extensive broadcasting of data in units of Gigabit

5. Transporter class gateway with unmatched performance

6. Widely accurate traffic statistics

7. Remote bandwidth management options

8. Up to 30MBPS of data connectivity speed

9. Great support for VPS support

10. Highest downloading and uploading speed

11. Enhanced and improved global connectivity 


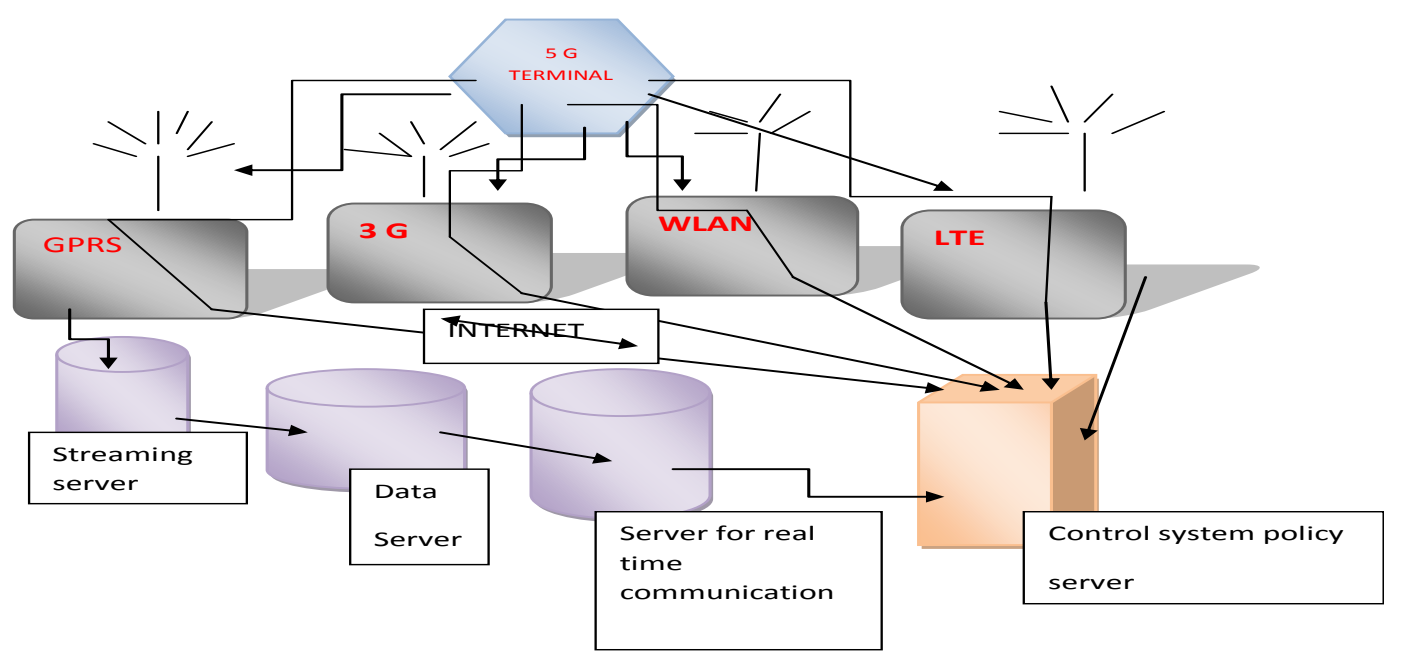

Fig 1: Design of 5G Mobile Network

\section{COMPARISON OF 1G-5G TECHNOLOGIES [6].}

Table 1. Comparison table of 1G-5G Technology.

\begin{tabular}{|c|c|c|c|c|c|}
\hline $\begin{array}{c}\text { Generation } \\
(\mathbf{1 G}, \mathbf{2 G , 3 G , 4} \\
\text { G,5G) }\end{array}$ & Definition & $\begin{array}{c}\text { Throughput } \\
\text { Speed }\end{array}$ & Technology & $\begin{array}{l}\text { Time } \\
\text { period }\end{array}$ & Features \\
\hline $1 \mathrm{G}$ & Analog & $\begin{array}{l}14.4 \mathrm{Kbps} \\
\text { (peak) }\end{array}$ & AMPS,NMT,TACS & $\begin{array}{c}1970- \\
1980\end{array}$ & $\begin{array}{l}\text { During } 1 \mathrm{G} \text { Wireless phones are } \\
\text { used for voice only. }\end{array}$ \\
\hline $2 G$ & $\begin{array}{c}\text { Digital } \\
\text { narrow } \\
\text { band circuit } \\
\text { data }\end{array}$ & 9.6/14.4 Kbps & TDMA,CDMA & $\begin{array}{l}1990 \text { to } \\
2000\end{array}$ & $\begin{array}{l}\text { 2G capabilities are achieved by } \\
\text { allowing multiple users on a } \\
\text { single channel via multiplexing. } \\
\text { During } 2 \mathrm{G} \text { Cellular phones are } \\
\text { used for data also along with voice. }\end{array}$ \\
\hline $2.5 \mathrm{G}$ & Packet Data & $\begin{array}{c}171.2 \\
\text { Kbps(peak) } \\
20-40 \mathrm{Kbps}\end{array}$ & GPRS & $2001-2004$ & $\begin{array}{l}\text { In } 2.5 \mathrm{G} \text { the internet becomes } \\
\text { popular and data becomes more } \\
\text { relevant.2.5G Multimedia services } \\
\text { and streaming starts to show } \\
\text { growth .Phones start supporting } \\
\text { web browsing though limited and } \\
\text { very few phones have that. }\end{array}$ \\
\hline 3G & $\begin{array}{c}\text { Digital } \\
\text { Broadband } \\
\text { Packet Data }\end{array}$ & $\begin{array}{c}\text { 3.1 Mbps } \\
\text { (peak) } \\
\text { 500-700 Kbps }\end{array}$ & $\begin{array}{c}\text { CDMA } 2000 \\
\text { (1xRTT, EVDO) } \\
\text { UMTS, EDGE }\end{array}$ & $2004-2005$ & $\begin{array}{l}\text { 3G has Multimedia services } \\
\text { support along with streaming are } \\
\text { more popular. In } 3 \mathrm{G} \text {, Universal } \\
\text { access and portability across } \\
\text { different device types are made } \\
\text { possible. (Telephones, PDA's, } \\
\text { etc.) }\end{array}$ \\
\hline 3.5G & Packet Data & $\begin{array}{l}\text { 14.4 Mbps } \\
\text { (peak) }\end{array}$ & HSPA & $\begin{array}{c}2006- \\
2010\end{array}$ & $\begin{array}{l}3.5 \mathrm{G} \text { supports higher throughput } \\
\text { and speeds to support higher data }\end{array}$ \\
\hline
\end{tabular}




\begin{tabular}{|c|c|c|c|c|c|}
\hline & & 1-3 Mbps & & & needs of the consumers. \\
\hline $4 \mathrm{G}$ & $\begin{array}{l}\text { Digital } \\
\text { Broadband } \\
\text { Packet } \\
\text { All IP } \\
\text { Very high } \\
\text { throughput }\end{array}$ & $\begin{array}{c}\text { 100-300 Mbps } \\
\text { (peak) } \\
\text { 3-5 Mbps } \\
100 \mathrm{Mbps}(\mathrm{Wi}- \\
\text { Fi) }\end{array}$ & $\begin{array}{c}\text { WiMAX LTE } \\
\text { Wi-Fi }\end{array}$ & $\begin{array}{l}\text { Now (Read } \\
\text { more } \\
\text { on } \\
\text { Transitioni } \\
\text { ng } \\
\text { to } 4 \mathrm{G})\end{array}$ & $\begin{array}{l}\text { Speeds for } 4 \mathrm{G} \text { are further increased } \\
\text { to keep up with data access demand } \\
\text { used by various services. High } \\
\text { definition streaming is now } \\
\text { supported in } 4 \mathrm{G} \text {. New phones with } \\
\text { HD capabilities surface. It gets } \\
\text { pretty cool. In } 4 \mathrm{G} \text {, Portability is } \\
\text { increased further. World-wide } \\
\text { roaming is not a distant dream. }\end{array}$ \\
\hline 5G & Not Yet & $\begin{array}{c}\text { Probably } \\
\text { gigabits }\end{array}$ & Not Yet & $\begin{array}{c}\text { Soon } \\
\text { (probably } \\
2020 \text { ) }\end{array}$ & $\begin{array}{l}\text { Currently there is no 5G } \\
\text { technology deployed. When this } \\
\text { becomes available it will provide } \\
\text { very high speeds to the consumers. } \\
\text { It would also provide efficient } \\
\text { use of available bandwidth as has } \\
\text { been seen through development of } \\
\text { each new technology. }\end{array}$ \\
\hline
\end{tabular}

\section{FUTURE WORK AND CONCLUSION}

Every national and international parties has their standard to integrate these all standard of telecommunication architecture. They all have different architecture for interconnection. If common architecture for ALL IP for traffic control to provide super fine services for wireless because vision of super core is based on IP platform. With very inception of 5G technology, the international cellular telephony will be changed from the scratch. In easy terms you can understand that the international mobility is going $\mathrm{t}$ be localize with more and more feature and utilities. 5G Technology will certainly upgrade the gadget, PDA and I Phone mania among the global users. This entirely new concept in the mobile communication is equipped with highly advanced operating systems and gigantic data storage in the affordable rates and in amazing lightening speed [7]. Telecommunication industry has launched this brand new technology to overcome the technical bottlenecks and limitations of other applications prevailed in previous versions of the technological enhancements. 5G technology has extraordinary data capabilities and has ability to tie together unrestricted call volumes and infinite data broadcast within latest mobile operating system. 5G technology has a bright future because it can handle best technologies and offer priceless handset to their customers. May be in coming days 5G technology takes over the world market. 5G Technologies have an extraordinary capability to support Software and Consultancy. The Router and switch technology used in $5 \mathrm{G}$ network providing high connectivity. The 5G technology distributes internet access to nodes within the building and can be deployed with union of wired or wireless network connections. The current trend of 5G technology has a glowing future.

\section{REFERENCES}

[1] Ganchev, M.O'Droma, H.Chaouchi, I.Armuellus, M.Siebert, N.Houssos "Requirements for an Integrated System and Service 4G Architecture" IEEE 2004.
[2]Jun-Zhao Sun, Jaakko Sauvola, and Douglas Howie "Features in Future: 4G Vision from a Technical 5Perspective", IEEE 2001.

[3] Jahangir Khan, Ali Abbas, 4g and advance technology, International Journal of Computer Applications (0975 8887) Volume 21- No.2, May 2011

[4] Frattasi, S.; Fathi, H.; Fitzek, F.H.P.; Katz, M.D.; Prasad, R. Defining 4G Technology from the User's Perspective. IEEE Volume 20, Issue 1, Jan.-Feb. 2006, Page(s):35 41.

[5] Puneet Gupta, Wireless developer Networks, Mobile Wireless Communications Tomorrow [Online] Available:

www.wirelessdevnet.com/channels/wireless/training/

[6] Santhi, K.R.; Srivastava, V.K. ; SenthilKumaran, G.; Butare, A. Goals of True Broad band's Wireless Next

Wave (4G-5G). Vehicular Technology Conference, 2003. VTC 2003-Fall. 2003 IEEE 58th, Volume 4, Oct.2003,

Pages(s): 2317-2321.

[7] Suvarna Patil, International Journal of Engineering and Innovative Technology (IJEIT) Volume 1, Issue 1,January 2012

[8] Toni Janevski, 5G Mobile Phone Concept, Consumer Communications and Networking Conference, 2009 6th IEEE [1-4244-2308-2].

[9] K.R.Santh, Goals Of True Broad band's Wireless Next Wave (4G-5G), 0-7803-7954-3/03/\$17.00 @2003 IEEE.

[10] J. B. Chia, "Video services over 4G wireless networks: not necessarily Streaming," Wireless Communications and Networking Conference, 2002. WCNC2002. 2002 IEEE , Volume: 1 , 17-21 March 2002 , pp:18 - 22 vol. 